\title{
Quantification of overall migration levels from poly (vinyl chloride) films: Effects of gamma and electron beam radiation
}

\author{
Quantificação de migrantes totais de embalagens de filmes de poli (cloreto de vinila): Efeitos \\ da radiação gama e radiação com feixe de elétrons
}

\author{
1,(DF́ábio Cerdeira LIRIO, 1,*(D) Mauro Carlos Lopes SOUZA, 1, (D) Bluma Guenther SOARES, 2, (D) Valéria Barbosa

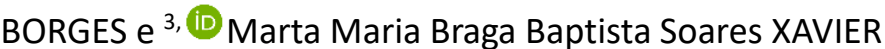

1 Universidade Federal do Rio de Janeiro. Laboratório de instrumentação nuclear (LIN) do Instituto Alberto Luiz Coimbra de Pós Graduação e Pesquisa de Engenharia (COPPE). Centro de Tecnologia - Av. Horácio Macedo, 2030 - 101 - Cidade Universitária, CEP 21941-450. Rio de Janeiro-RJ, Brasil.

2 Universidade Federal do Rio de Janeiro. Escola de Química. Departamento de Ciência de Alimentos. Av. Athos da Silveira Ramos, 149 - Cidade Universitária, CEP 21044-020. Rio de Janeiro-RJ, Brasil.

3 Faculdade de Medicina Veterinária de Valença. Rua Sargento Vítor Hugo no 161. Bairro de Fátima. Valença -RJ, Brasil

*Corresponding author: mauroclsouza@hotmail.com

\section{ABSTRACT}

OPPEN ACESS

\section{Additional information}

Received: 01/19/2017

Accept: 02/14/2017

Published: 08/07/2017

Editor:

Neila Mello S. Cortez Universidade Federal de Pernambuco, PE.

neilacortez@yahoo.com.br

\section{Double blind reviews}

Reviews process

Prot. 1352017R01 (Brazil)

Prot. 1352017R02 (Brazil)

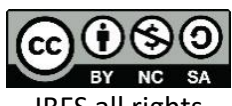

JBFS all rights

Copyright: () 2017
This study investigated the overall migration from Poly (vinyl chloride) (PVC) films into food simulants, after gamma irradiation $\left({ }^{60} \mathrm{Co}\right)$ or electron beam radiation. PVC films containing di-(2ethylhexyl) adipate (DEHA) and epoxidized soybean oil were stored under controlled temperature $\left(24 \pm 1^{\circ} \mathrm{C}\right)$ and moisture $(50 \pm 5 \%)$ for 2 days. These films were supported on a stainless-steel plates and specimens were subjected to ionizing radiation treatment with gamma radiation from a ${ }^{60} \mathrm{Co}$ source (dose rate $=20 \mathrm{~Gy} \cdot \mathrm{min}^{-1}$ ) or electron beam radiation (dose rate $=120 \mathrm{~Gy} \cdot \mathrm{min}^{-1}$ ) at absorbed doses equal to $0,10,25$ and $50 \mathrm{kGy}$. Overall packing migrants were evaluated on different food simulants (distilled water, $3 \% \mathrm{w} / \mathrm{v}$ acetic acid and $10 \% \mathrm{v} / \mathrm{v}$ ethanol) as a function of time $(24,48$ and 72 hours). Results of overall migration levels showed that the treatment with radiation doses above $10 \mathrm{kGy}$ promoted a significant increase of the overall packing migrants levels into all aqueous food simulants $(p<0.05)$. The increase of overall packing migrants induced by gamma rays or electron beam radiation was associated with radiolysis reaction, which could rise low molecular weight radiolysis products with a higher mobility into food simulants. The increase of discontinuous of polymer due to radiolysis could also explain the increase of packing migrants after irradiation procedure. Overall migration levels were also enhanced with increasing exposure time to food simulants.

Keywords: Food Packaging. Gamma Radiation. Electron Beam. Migration.

\section{RESUMO}

Este estudo investigou a difusão total de migrantes de embalagem de filmes de poli (cloreto de vinila) (PVC) para simulantes de alimentos, após a irradiação com radiação gama $\left({ }^{60} \mathrm{Co}\right)$ e radiação por feixe de elétrons. Os filmes de PVC contendo adipato de dioctila (DOA) e óleo de soja epoxidado foram acondicionados sob temperatura $\left(24 \pm 1^{\circ} \mathrm{C}\right)$ e umidade $(50 \pm 5 \%)$ controladas durante 2 dias. Os filmes foram fixados em placas de aço inoxidável e os espécimes foram submetidos ao tratamento com radiação ionizante com radiação gama de fonte de ${ }^{60} \mathrm{Co}$ (taxa de dose $=20 \mathrm{~Gy} / \mathrm{min}$ ) ou radiação por feixe de elétrons (taxa de dose $=120 \mathrm{~Gy} / \mathrm{min}$ ) para doses de radiação absorvidas iguais a 0,10 , 25 e $50 \mathrm{kGy}$. Os migrantes totais de embalagem foram avaliados em diferentes simulantes de alimentos (água destilada, solução $3 \%$ p/v ácido acético e solução $10 \%$ v/v etanol) em função do tempo ( 24,48 e 72 horas). Os resultados das avaliações de migrantes de embalagem mostraram que o tratamento com doses de radiação superiores a $10 \mathrm{kGy}$ promoveram o aumento significativo dos níveis de migrantes totais de embalagem para todos os simulantes aquosos de alimentos $(p<0.05)$. $O$ aumento dos níveis de migrantes de embalagem induzidos pela radiação gama ou radiação por feixe de elétrons foi associado com as reações radiolíticas que podem elevar a concentração de produtos radiolíticos de baixo peso molecular que apresentam alta mobilidade para os simulantes de alimentos. $\mathrm{O}$ aumento da descontinuidade das cadeias poliméricas devido às reações radiolíticas também poderia explicar o incremento dos níveis de migrantes de embalagem após o procedimento de irradiação. Os níveis totais de migrantes de embalagem também foram aumentados com a ampliação do tempo de exposição aos simulantes de alimentos.

Palavras-chave: Embalagem de alimentos. Radiação Gama. Feixe de Elétrons. Migração. 


\section{INTRODUCTION}

Maintaining the original physicochemical, microbiological and sensory properties during all the food chain processing is one of the most important roles of food packaging materials, in order to assure food safety and quality. Nowadays, the food packaging materials have a broad spectrum of technological functions. The primary technological function of food packaging is providing an efficient barrier to external agents, such as heat, UV radiation, dirtiness, insects and microbes (MARSH; BUGUSU, 2007).

Food packaging also controls gaseous exchange (moisture, oxygen, nitrogen, carbon dioxide and ethylene) and has a direct informative function as food labels (ROBERTSON, 2016; WEINRICH; SPILLER, 2016).

Conventional synthetics polymers (polypropylene, polyethylene, polystyrene, poly (vinyl chloride) and poly (ethylene terephthalate)) are commonly used as food packaging materials because of desirable properties as lightness, efficient barrier function, high production volume, good extensibility and durability (ROMANI et al., 2017). Thus, polymer food packaging materials plays an essential role on development of plastics used to wrap fresh, minimally processed and ready-to-eat foodstuffs (MARSH; BUGUSU, 2007).

Of plastics, poly (vinyl chloride) has a large advantage against other thermoplastic synthetic polymers due to its extensive capacity of additives incorporation during processing and transformation steps (Yu et al., 2016). Among the additives used on PVC formulations, the plasticizers are use in large concentrations up to $50 \% \mathrm{w} / \mathrm{w}$ (CHIELLINI et al., 2013).

Plasticizers are organic molecules with multiple esters functional groups, which are responsible for the separation of polymeric chains (MADALENO et al., 2009). Therefore, the plasticizers incorporation during the processing of the PVC resin allows the production of extensible plasticized PVC food packaging materials as stretching and shrinkable PVC films (BONINI et al., 2008; COLTRO et al., 2013). On PVC films synthesis, plasticizers as phthalates, adipates, citrates and sebacates are the main additives employed (COLTRO et al., 2013). As a critical concern, plasticizers molecules has low molecular weight and presents no strong chemical interactions with polymeric chains. These characteristics observed for plasticizers and other additives allow the physicochemical phenomenon of migration (SÉNDON GARCIA et al., 2006; ZYGOURA et al., 2007; CHIELLINI et al., 2013; COLTRO et al., 2014).

The migration of additives could be described as a two steps process: initially, the additives diffuse from internal polymeric matrix to external surface in contact with foodstuffs or a food simulant. Subsequently, the additives migrate from external surface area to foods or food simulant (LAU; Wong, 2000; MARCILLA et al., 2008; COLTRO et al., 2014). On a toxicological standpoint, the migration of additives, such as phthalates, could increase consumer exposure to xenobiotic toxic molecules. Many scientific reports show that chronic exposure to phthalates from plasticized packaging materials may increase glandular functions modifications (endocrine disrupture) and reproductive toxicity (HAUSER; CALAFAT, 2005; BOISVERT et al., 2016).

Several aspects may modify the migration behavior of low molecular weight additives from food packaging materials into foodstuffs/food simulants. The main factors are type of polymer, chemical nature of additives, thickness of packaging material, initial concentration of each additive, efficacy of additives incorporation during polymer processing, polarity of foodstuffs/food simulants and physical variables as time and temperature (ZYGOURA et al., 2007).

The treatment with ionizing radiation (gamma or electron beam radiation) is frequently apply to eliminate pathogenic microorganisms on prepackaged foodstuffs 
(GOULAS et al., 2004; SHIM et al. 2012). Gamma rays and electron beam radiation could promote radiolysis of food packaging materials due to homolytic scission of chemical bonds presents on polymer structure (HAJI-SAEID et al., 2007). The main radiolysis reactions that occurs during irradiation of food packaging materials are chain scission, reticulation, hydroperoxides formation and depolymerization (GOULAS et al., 2004; COLOMBANI et al., 2007; ZYGOURA et al., 2011a). Since irradiation causes chemical and structural changes on polymeric chains, irradiation parameters as doses rates, absorbed doses, homogeneity of doses, atmosphere, temperature, and moisture could also influence the overall migration of additives (ZYGOURA et al., 2007).

The aim of this study was to evaluate the influence of high radiation doses (10 $50 \mathrm{kGy})$ of gamma radiation $\left({ }^{60} \mathrm{Co}\right)$ and electron beam radiation on overall packing migrants of additives presents on PVC films into different food simulants (distilled water, $3 \% \mathrm{w} / \mathrm{v}$ acetic acid, $10 \% \mathrm{v} / \mathrm{v}$ ethanol and $96 \% \mathrm{v} / \mathrm{v}$ ethanol).

\section{MATERIAL AND METHODS}

\section{Preparation of the PVC polymer films}

PVC food packaging materials were commercial stretch PVC polymer films compounded by PVC resin, di-(2-ethylhexyl) adipate (DEHA) (30 pcr) as main plasticizer and epoxidized soybean oil ( 2 pcr) as stabilizer. After acquisition, PVC films were cut into regular dimensions of $600 \mathrm{~cm}^{2}$. Specimens were stored sheltered from light and under controlled temperature $\left(24 \pm 1^{\circ} \mathrm{C}\right)$ and moisture $(50 \pm 5 \%)$ for 2 days before the ionizing radiation treatment.

\section{Irradiation of the PVC polymer films}

On the third day, PVC films specimens were supported on stainless steel plates. Supported specimens were exposed to one of ionizing radiation treatments: gamma radiation from a ${ }^{60} \mathrm{Co}$ source $(20 \mathrm{~Gy} / \mathrm{min})$ or electron beam $(10 \mathrm{MeV})$ radiation $(120$ $\mathrm{Gy} / \mathrm{min}$ ) at doses equal to 0, 10, 25 and $50 \mathrm{kGy}$. Irradiation procedures were carried out under aerobic atmosphere and room temperature.

\section{Overall packing migrant evaluation}

Unirradiated and irradiated (gamma rays or electron beam radiation) PVC films specimens with area equal to $600 \mathrm{~cm}^{2}$ were cut into regular squares of $1 \mathrm{~cm}^{2}$ in order to increase surface contact area with food simulants used in the migration tests. After specimen preparation, all samples were washed thoroughly with tap water and distilled water to avoid the presence of possible interferers. After wash out procedure, samples were dried at room temperature.

The extraction jars were filled with $300 \mathrm{~mL}$ of each food simulants (distilled water, $3 \% \mathrm{w} / \mathrm{v}$ acetic acid or $10 \% \mathrm{v} / \mathrm{v}$ ethanol). Overall packing migrant tests were conducted maintaining a ratio of area of specimens (both sides exposure) in contact with food simulant equal to $2 \mathrm{~cm}^{2}$ per $1 \mathrm{~mL}$ of each food simulant. Subsequently, the extraction jars were sealed with a glass cover and systems containing extraction jars and food simulants were placed on a thermostatic bath to ensure that food simulant temperature was balanced with thermostatic bath before the initiation of overall migration tests. Then, the dried samples were placed in direct contact into food simulant. The temperature used on overall migrant evaluation was $40 \pm 1^{\circ} \mathrm{C}$ for all aqueous food simulants (distilled water, $3 \% \mathrm{w} / \mathrm{v}$ acetic acid or $10 \% \mathrm{v} / \mathrm{v}$ ethanol). The overall packing migrant tests were executed at times intervals of 24,48 and 72 hours. All tests were executed in five replicates. 
After the selected time intervals, the specimens were washed out for three times with food simulant employed on each overall migration tests in order to extract possible additives molecules retained on PVC films surface. The blank tests were conducted with each food simulant to eliminate the influence of interferents on results.

The overall migrant levels for unirradiated and irradiated (gamma or electron beam radiation) PVC films specimens were compared with international standard value of $8 \mathrm{mg} \cdot \mathrm{dm}^{-2}$ for aqueous food simulants.

\section{Statistical analysis of data}

Overall migrant quantification experiments were conducted in five replicates for each experimental condition. Means values and standard deviations were calculated for all experimental data. Statistical differences between samples were evaluated by Student's t test with a significance level of $5 \%(p<0.05)$.

\section{RESULTS AND DISCUSSION}

\section{Quantification of Overall Packing Migrants (OPM)}

The Overall migrant levels into food simulant distilled water at $40 \pm 1^{\circ} \mathrm{C}$ are shown on Figure 1.

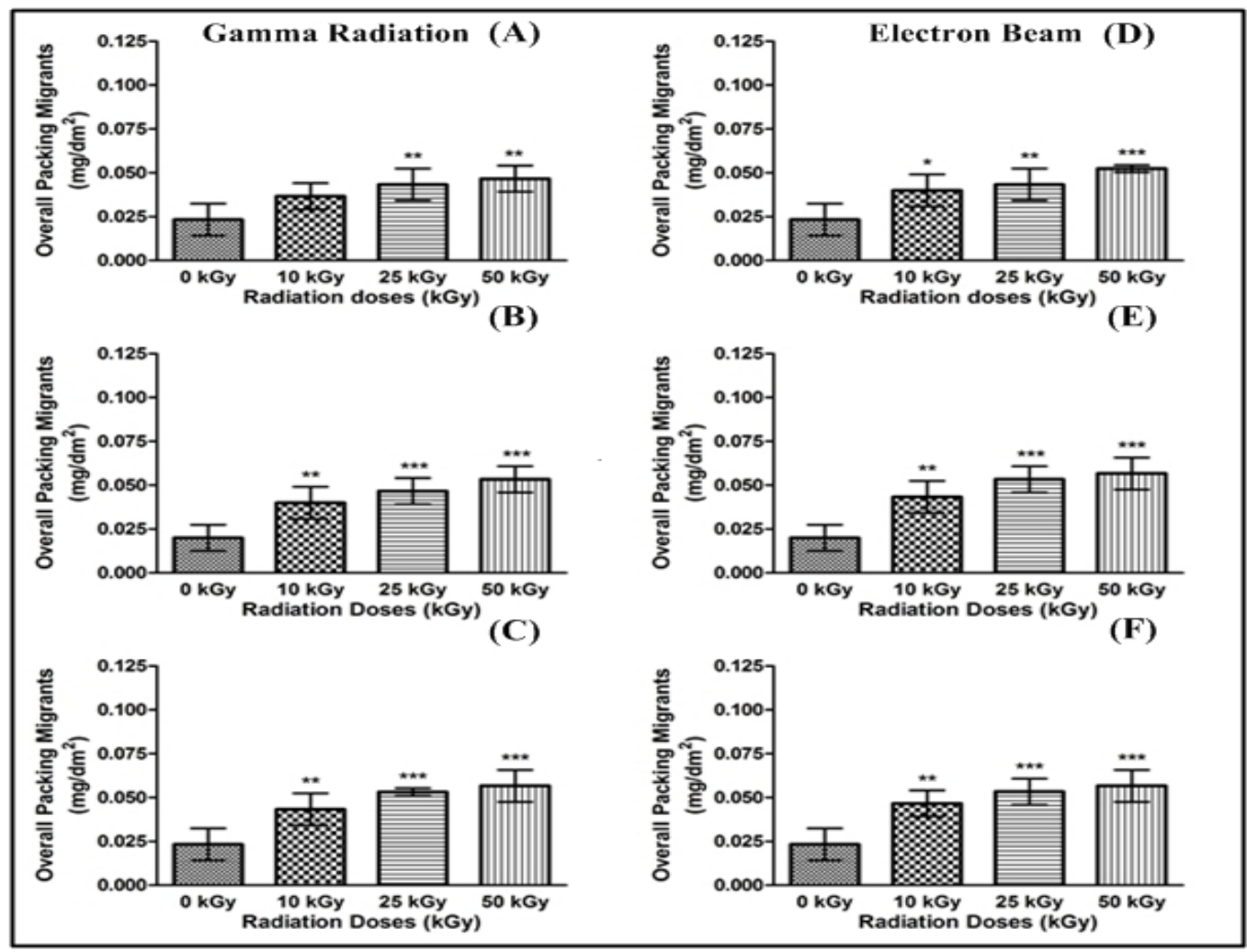

Figure 1. Overall migration for unirradiated and irradiated (gamma or electron beam radiation) PVC films into distilled water. Legend: (A) and (D) $24 \mathrm{~h}$ exposure; (B) and (D) $48 \mathrm{~h}$ exposure; (C) and (F) $72 \mathrm{~h}$ exposure. ${ }^{* ; * ; * * * *}$ The asterisks demonstrate degree of difference between the irradiated samples in comparison with unirradiated PVC films $(\mathrm{p}<0.05)$.

Figure 1 shows that the overall packing migrants (OPM) concentrations are increased on gamma or electron beam irradiated PVC films in comparison with unirradiated samples. The overall migration level into distilled water ranges from 0.023 to $0.024 \mathrm{mg} . \mathrm{dm}^{-2}$ for unirradiated samples after $72 \mathrm{~h}$ of exposure (Figure $1 \mathrm{~A}$ to $1 \mathrm{~F}$ ). For 
50 kGy gamma irradiated PVC films, OPM varies from 0.047 to $0.057 \mathrm{mg} . \mathrm{dm}^{-2}$ (Figure $1 \mathrm{~A}$ to $1 \mathrm{C}$ ) and for $50 \mathrm{kGy}$ electron beam irradiated samples the OPM levels ranged from 0.052 to $0.057 \mathrm{mg} . \mathrm{dm}^{-2}$ (Figure 1D to $1 \mathrm{~F}$ ) after 72 hours of contact with distilled water at $40 \pm 1^{\circ} \mathrm{C}$.

As shown in Figure 1, the increase of overall migration levels into distilled water is proportional to the rise of absorbed radiation doses up to $50 \mathrm{kGy}$. As the exposure time enhances ( 24 to 72 hours) occurs, the increase of overall migration is also observed for all experimental conditions. Statistical analysis of experimental data shown that irradiated PVC films (gamma or electron beam radiation) with absorbed radiation doses of 10, 25 and $50 \mathrm{kGy}$ presented a significant statistical increase of overall packing migrants levels into distilled water at $40 \pm 1^{\circ} \mathrm{C}$ after 48 and 72 hours of exposure. No significant increase of overall migrants was reported for $10 \mathrm{kGy}$ gamma irradiated PVC films after 24 hours of extraction with distilled water. This observation agreed with previous studies conducted by Zygoura et al. (2011a) and Zygoura et al. (2011b).

However, after 72 hours of extraction, low levels of overall migrants diffuse from unirradiated and irradiated samples into distilled water. The maximum OPM value was

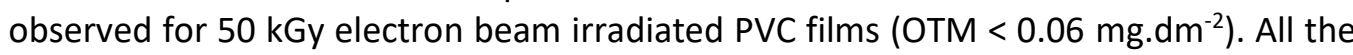
experimental overall packing migrant levels described for food simulant distilled water were in agreement with regulatory limits (OTM $<8 \mathrm{mg} \cdot \mathrm{dm}^{-2}$ ).

Figure 2 shown the overall migration levels into food simulant $3 \% \mathrm{w} / \mathrm{v}$ acetic acid at $40 \pm 1^{\circ} \mathrm{C}$.
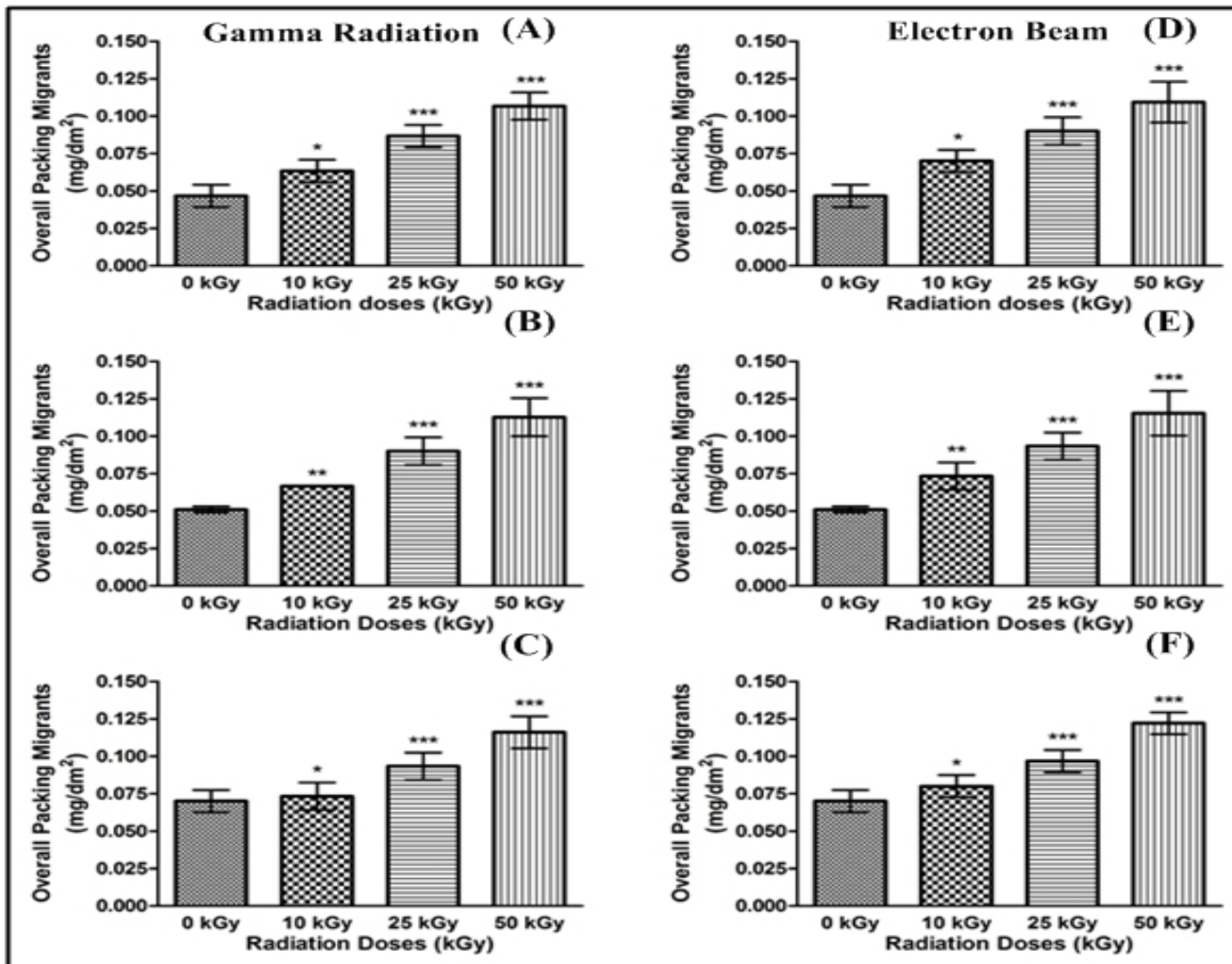

Figure 2. Overall migration for unirradiated and irradiated (gamma or electron beam radiation) PVC films into $3 \% \mathrm{w} / \mathrm{v}$ acetic acid. Legend: (A) and (D) $24 \mathrm{~h}$ exposure; (B) and (D) $48 \mathrm{~h}$ exposure; (C) and (F) 72 h exposure. ${ }^{* * * * * * * *}$ The asterisks demonstrate degree of difference between the irradiated samples in comparison with unirradiated PVC-films $(\mathrm{p}<0.05)$.

The diffusion of overall migrants into acidic simulant $3 \% \mathrm{w} / \mathrm{v}$ acetic acid is shown of Figure $2 \mathrm{~A}$ to $2 \mathrm{~F}$. Gamma and electron beam irradiation at high doses above $10 \mathrm{kGy}$ promoted a significant increase in overall packing migration levels. For unirradiated samples, the increase of OPM values ranged from 0.047 to $0.070 \mathrm{mg} \cdot \mathrm{dm}^{-2}$, between 24 
and 72 hours of extraction with simulant B. For $50 \mathrm{kGy}$ irradiated PVC films, the OPM levels values varied from 0.100 to $0.110 \mathrm{mg} . \mathrm{dm}^{-2}$ and from 0.110 to $0.120 \mathrm{mg} \cdot \mathrm{dm}^{-2}$ for gamma and electron beam irradiated samples, respectively, after 72 hours of exposure into $3 \% \mathrm{w} / \mathrm{v}$ acetic acid (simulant B) (Figures $2 \mathrm{~A}$ to $2 \mathrm{~F}$ ).

Furthermore, the diffusion process illustrated by Figure $2 \mathrm{~A}$ to $2 \mathrm{~F}$ suggests that packing migrants diffuse through a high rate on short time intervals (less than 24 hours). Then, after 24 hours exposure to simulant $B$, the diffusional rate decreases due to increase of concentration of packing migrants on contact interface between specimens and food simulant $B$.

Migration data observed for food simulant $3 \% \mathrm{w} / \mathrm{v}$ acetic acid suggests a low toxicological risk due to low levels of overall migrants reported for unirradiated and irradiated PVC films after 72 hours of extraction at $40 \pm 1^{\circ} \mathrm{C}\left(0.070\right.$ to $\left.0.120 \mathrm{mg} \mathrm{dm}^{-2}\right)$. These values are also in accordance with international regulation standards for maximum levels of OPM $<8.0 \mathrm{mg} \cdot \mathrm{dm}^{-2}$ for aqueous food simulants.

Figure 3 shows the overall migration values for unirradiated and irradiated PVC films into $10 \% \mathrm{v} / \mathrm{v}$ ethanol at $40 \pm 1^{\circ} \mathrm{C}$.

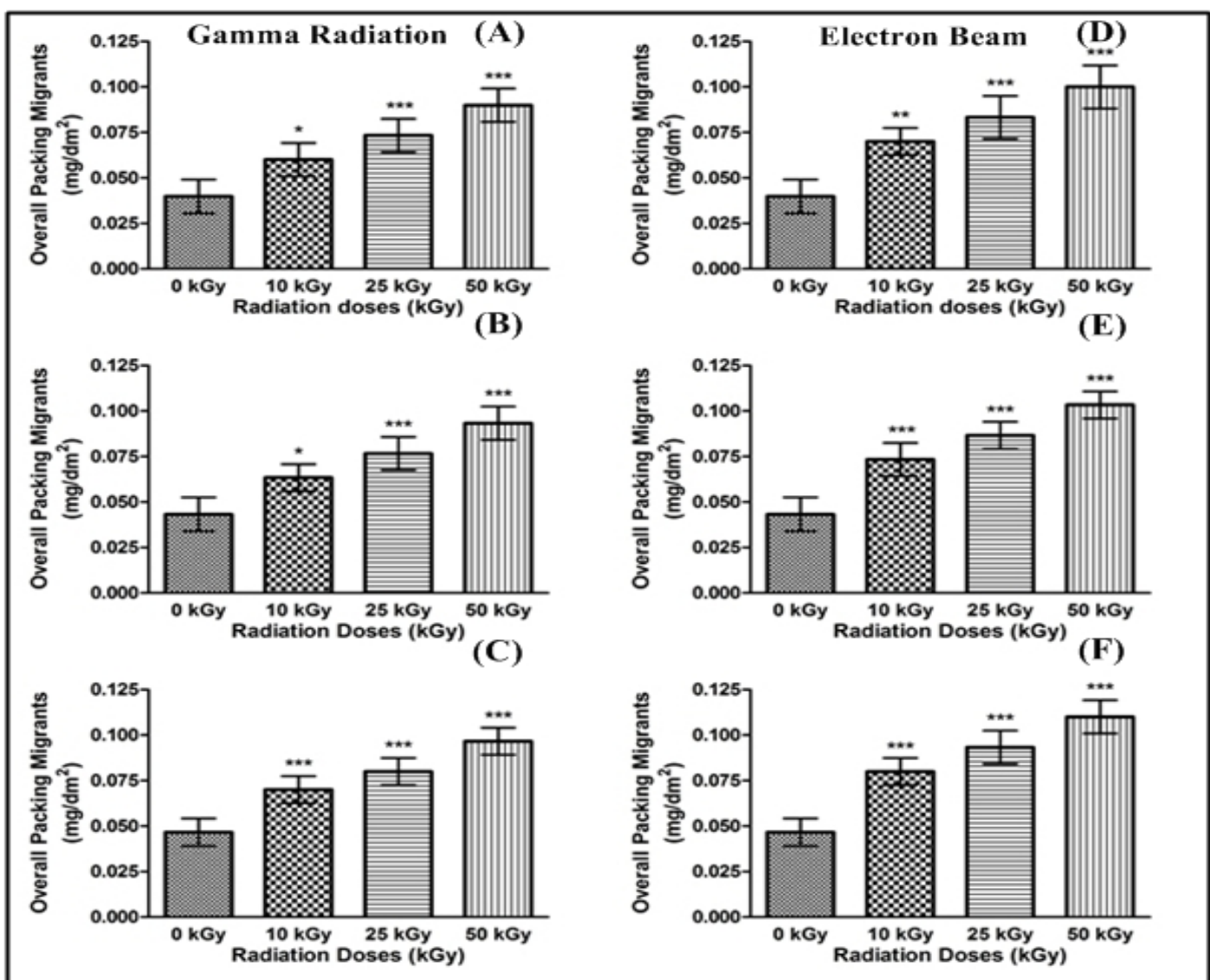

Figure 3. Overall migration for unirradiated and irradiated (gamma or electron beam radiation) PVC films into $10 \%$ v/v ethanol. Legend: (A) and (D) $24 \mathrm{~h}$ exposure; (B) and (D) $48 \mathrm{~h}$ exposure; (C) and (F) $72 \mathrm{~h}$ exposure. ${ }^{* ; * * * * * *}$ The asterisks demonstrate degree of difference between the irradiated samples in comparison with unirradiated PVC films $(\mathrm{p}<0.05)$.

The levels of overall packing migrants into $10 \% \mathrm{v} / \mathrm{v}$ ethanol ranged from 0.040 to $0.047 \mathrm{mg} . \mathrm{dm}^{-2}$ for unirradiated PVC films. Samples irradiated with $50 \mathrm{kGy}$ of gamma or electron beam radiation presented levels of OPM from $0.090-0.097 \mathrm{mg} \cdot \mathrm{dm}^{-2}$ and 0.100 to $0.1100 \mathrm{mg} \cdot \mathrm{dm}^{-2}$, respectively (Figure 3A to $3 \mathrm{~F}$ ). As reported in Figures 1 and 2, the increase of ionizing radiation absorbed doses also raised the concentration of packing migrants that diffuses into simulant C (10 \% v/v ethanol). Statistical analysis of data 
reveals that radiation doses above $10 \mathrm{kGy}$ of both irradiators systems (gamma rays and electron beam) promoted a significant increment of packing migrants $(p<0.05)$. Data obtained for all experimental conditions using $10 \% \mathrm{v} / \mathrm{v}$ ethanol as food simulant are in agreement with international regulatory agencies, which defines the OPM limits of 8 $\mathrm{mg} \cdot \mathrm{dm}^{-2}$.

By comparing overall migration levels into all aqueous food simulants (distilled water, $3 \% \mathrm{w} / \mathrm{v}$ acetic acid and $10 \% \mathrm{v} / \mathrm{v}$ ethanol) there was a direct correlation between the enhance of radiation doses $(10-50 \mathrm{kGy})$ with the increment of packing migrants flux into studied food simulants.

It well known that ionizing radiation promotes homolytic scission of polymer chains (COLOMBANI et al., 2007). These observations are possibly related with radiolysis reaction of polymer chains and the severity of chain scission of PVC, which may increase the production of oligomers, monomers and radiolysis products, such as free radicals species with low molecular weight (ZYGOURA et al., 2011a; ZYGOURA et al., 2011b). As radiation doses applied to PVC films increases is expected a proportional enhance of low molecular weight radiolysis products (COLOMBANI et al., 2007) that could migrate through the polymer food packaging material. Radiolysis of stabilizers additives and polymer chains could also be observed during high radiation doses treatment of PVC films. This fact facilities the migration of stabilizers additives radiolytic species (ZYGOURA et al., 2011b).

A second mechanism proposed for the rise of overall migration reported for all aqueous food simulants is closely associated with polymer chains ruptures that could create discontinuance on PVC film interface. This discontinuance area contributes to a direct contact among food simulants and additives molecules, which are frequently located between polymer chains.

The migration data demonstrated a low migration phenomenon for radiolysis products, oligomers, monomers and additives into distilled water in comparison with migration profile reported for $3 \% \mathrm{w} / \mathrm{v}$ acetic acid and $10 \% \mathrm{v} / \mathrm{v}$ ethanol. These findings are probably due to lipophilic nature of main packing migrants (oligomers, monomers, plasticizers, stabilizers and radiolysis products), which presents a low affinity with polar solvents as distilled water (GOULAS et al., 2004; ZYGOURA et al., 2007).

The most efficient extraction of overall packing migrants of simulant $B$ could also be justified by $\mathrm{pH}$ reduction of food simulant medium. The reduction of $\mathrm{pH}$ affects the diffusion of oligomers and additives from internal layers of PVC films into acidic foodstuffs/food simulants ( $\mathrm{pH}<4.5)$, as reported by Zygoura et al. (2011b).

Although the results observed for overall packing migrants in food simulant $3 \%$ $\mathrm{w} / \mathrm{v}$ acetic acid and $10 \% \mathrm{v} / \mathrm{v}$ ethanol showed a similar pattern, the values obtained for simulant $\mathrm{B}$ are slight higher than simulant $\mathrm{C}$. This finding are in accordance with previously data described by Zygoura et al. (2011b).

\section{CONCLUSIONS}

This study has investigated the overall packing migrants levels of PVC polymer films irradiated with different doses of gamma and electron beam radiation. The migration profile was evaluated into different aqueous food simulants (distilled water, $3 \% \mathrm{w} / \mathrm{v}$ acetic acid and $10 \% \mathrm{v} / \mathrm{v}$ ethanol). Irradiation at high doses produces an important increment in overall migrants levels into all aqueous food simulants. This report are possibly associate with radiolysis products (oligomers and free radical species) generate during ionizing radiation treatment. These radiolysis products can migrate more easily through polymer chains increasing overall migration values of irradiated samples. Another hypothesis is relate to chain scission of polymer induced by irradiation that rise the contact surface of plasticizers and food simulants due to discontinuance of polymer chains because of reduction of molecular weight. The radiolysis of additives molecules can 
contributes to an increase of molecular mobility, which mediates an increment of diffusion into food simulants.

The behavior of diffusion mechanism as a function of time of contact of irradiated samples with food simulants shows a first step based on a fast diffusion rate that occurs before 24 hours of exposure. Subsequently, packing migrants continue to diffuse in a slower rate. Although overall packing migrants levels show a significant increase, no toxicological risks were report as OPM values are not close from reference values.

\section{ACKNOWLOGDES}

Acknowledgments to Instituto de Macromoléculas Professora Eloísa Mano (IMA), Laboratório de Instrumentação Nuclear, Escola de Química, Centro de Tecnologia, Universidade Federal do Rio de Janeiro (UFRJ) and specially to Laboratório de Controle Bromatológico (LabcBrom/UFRJ).

\section{AUTHOR CONTRIBUITION}

The Professors Dr. Mauro Carlos Lopes Souza and Dra. Bluma Guenther Soares, Pós-Graduation Programm in Technology of Chemical and Biochemical Process, TPQB/UFRJ, accompanied the studies of nuclear radiation, irradiation of samples and participated in the experimental planning and drafted the manuscript. The Professor Dr. Marta Maria Braga Baptista Soares Xavier and Dr. Valéria Barbosa Borges for accompanied the irradiation proceduresnas well approval of the final manuscript proof.

\section{CONFLICT OF INTEREST}

The authors declare that there are no conflict of interest.

\section{FUNDING}

This research received no specific grant from any funding agency in the public, commercial, or not-forprofit sectors.

\section{REFERENCES}

BOISVERT, A.; JONES, S.; ISSOP, L.; ERYTHROPEL, H. C.; PAPADOPOULOS, V.; CULTY, M. In vitro functional screening as a means to identify new plasticizers devoid of reproductive toxicity, Environmental Research, v.150, p.496-512, 2016. DOI: $10.1016 / j$.envres.2016.06.033

BONINI, M.; ERRANI, E.; ZERBINATI, G.; FERRI, E.; GIROTTI, S. Extraction and gas chromatographic evaluation of plasticizers content in food packaging films, Microchemical Journal, v.90, n.1, p.31-36, 2008. DOI:10.1016/j.microc.2008.03.002

CHIELLINI, F.; FERRI, M.; MORELLI, A.; DIPAOLA, L.; LATINI, G. Perspectives on alternatives to phthalate plasticized poly (vinyl chloride) in medical devices applications, Progress in Polymer Science, v. 38, n. 7, p. 1067-1088, 2013. DOI:10.1016/j.progpolymsci.2013.03.001

COLOMBANI, J.; LABED, V.; JOUSSOT-DUBIEN, C.; PÉRICHAUD, A.; RAFFI, J.; KISTER, J.; ROSSI, C. High doses gamma radiolysis of PVC: mechanisms of degradation, Nuclear Instruments and Methods in Physics Research Section B, v.265, n.1, p.238-244, 2007. DOI:10.1016/j.nimb.2007.08.053

COLTRO, L.; PITTA, J. B.; MADALENO, E. Performance evaluation of new plasticizers for stretch PVC films, Polymer Testing, v.32, n.2, p.272-278, 2013. DOI:10.1016/j.polymertesting.2012.11.009

COLTRO, L.; PITTA, J. B.; DA COSTA, P. A.; PEREZ, M. A. F.; DE ARAÚJO, V. A.; RODRIGUES, R. Migration of conventional and new plasticizers from PVC films into food simulants: a comparative study, Food Control, v. 44, p. 118-129, 2014. DOI:10.1016/j.foodcont.2014.03.058 
GARCÍA, R. S.; SILVA, A. S.; COOPER, I.; FRANZ, R.; LOSADA, P. P. Revision of analytical strategies to evaluate different migrants from food packaging materials, Trends in Food Science \& Technology, v.17, n.7, p.354-366, 2006. DOI:10.1016/j.tifs.2006.01.005

GOULAS, A. E.; ZYGOURA, P.; KARATAPANIS, A.; GEORGANTELIS D.; KONTOMINAS, M. G. Migration of di(2ethylhexyl) adipate and acetyltributyl citrate plasticizers from food-grade PVC film into sweetened sesame paste (halawa tehineh): Kinetic and penetration study, Food and Chemical Toxicology, v.45, n.4, p.585-591, 2007. DOI:10.1016/j.fct.2006.10.003

HAJI-SAEID, M.; SAMPA, M. H. O.; CHMIELEWSKI, A. G. Radiation treatment for sterilization of packaging materials, Radiation Physics and Chemistry, v.76, p.1535-1541, 2007. DOI:10.1016/j.radphyschem.2007.02.068

HAUSER, R.; CALAFAT, A. M. Phthalates and human health, Occupational Environmental Medicine, v. 62, n. 11, p. 806-811, 2005. DOI:10.1136\%2Foem.2004.017590

LAU, O-W.; WONG, S-K. Contamination in food from packaging material, Journal of Chromatography A, v. 882, n.12, p. 255-270, 2000. DOI:10.1016/S0021-9673(00)00356-3

MADALENO, E.; ROSA, D. S.; ZAWADZKI, S. F.; PEDROZO, T. H.; RAMOS, L. P. Study of the use of plasticizer from renewable sources in PVC compositions, Polímeros, v.19, n.4, p.263-270, 2009. D0I:10.1590/S010414282009000400004

MARCILLA, A.; GARCIA, S.; GARCIA-QUESADA, J. C. Migrability of PVC plasticizers, Polymer Testing, v.27, n.2, p.221233, 2008. DOI:10.1016/j.polymertesting.2007.10.007

MARSH, K.; BUGUSU, B. Food packaging - Roles, Materials, and Environmental Issues, Journal of Food Science, v. 72, n. 3, p. R39-R55, 2007. DOI:10.1111/j.1750-3841.2007.00301.x

ROBERTSON, G. L. Packing and Food and Beverage Shelf Life. In: The Stability and Shelf Life of Food. $2^{\text {th }}$ edition, Woodhead Publishing: Australia, p.77-106, 2016. DOI:10.1533/9780857092540.1.244

ROMANI, V. P.; PRENTICE-HÉRNANDEZ, C.; MARTINS, V. G. Active and sustainable materials from rice starch, fish protein and orégano essential oil for food packaging, Industrial crops and Products, v.97, p.268-274, 2017. DOI:10.1016/j.indcrop.2016.12.026

SHIM, W-B.; JE, G-S.; KIM, K.; MTENGA, A.B.; LEE, W-G.; SONG, J-U.; CHUNG, D-H.; YOON, Y. Effect of irradiation on kinetic behavior of Salmonella Typhimurium and Staphylococcus aureus in lettuce and damage of bacterial cell envelope. Radiation Physics and Chemistry, v.81, p.566-571, 2012. DOI:10.1016/j.radphyschem.2012.01.008

YU, J.; SUN, L.; MA, C.; QIAO, Y.; YAO, H. Thermal degradation of PVC: a review, Waste Management, v. 48, p. 300314, 2016. DOI:10.1016/j.wasman.2015.11.041

WEINRICH, R.; SPILLER, A. Developing food labelling strategies: Multi-level labelling, Journal of Cleaner Production, v. 137, p. 1138-1148, 2016. DOI:10.1016/j.jclepro.2016.07.156

ZYGOURA, P. D.; GOULAS, A. E.; RIGANAKOS, K. A.; KONTOMINAS, M. G. Migration of di(2-ehtylhexyl) adipate and acetyltributyl citrate plasticizers from food-grade PVC film into isooctane: effect of gamma radiation, Journal of Food Engineering, v.78, n.3, p.870-877, 2007. DOI:10.1016/j.jfoodeng.2005.12.004

ZYGOURA, P. D.; PALEOLOGOS, E. K.; KONTOMINAS, M. G. Changes in the specific migration characteristics of packaging-food simulant combinations caused by ionizing radiation: effect of food simulant, Radiation Physics and Chemistry, v.80, n.8, p.902-910, 2011. DOI:10.1016/j.radphyschem.2011.03.020

ZYGOURA, P. D.; PALEOLOGOS, E. K.; KONTOMINAS, M. G. Migration levels of PVC plasticisers: effect of ionising radiation treatment, Food Chemistry, v.128, n.1, p.106-113, 2011. DOI:10.1016/j.foodchem.2011.03.002 